UCRL-ID-122196

\title{
Preliminary Report on the Black Thunder, Wyoming CTBT R\&D Experiment \\ Quicklook Report: LLNL Input from Regional Stations
}

P.E. Harben

RECEIVED

L.A. Glenn

MAY 17 ใละด

OSTI

This paper is submitted as

CTBT Seismic Research FY95 Deliverable No. 10 (S7.2.2)

October 1995

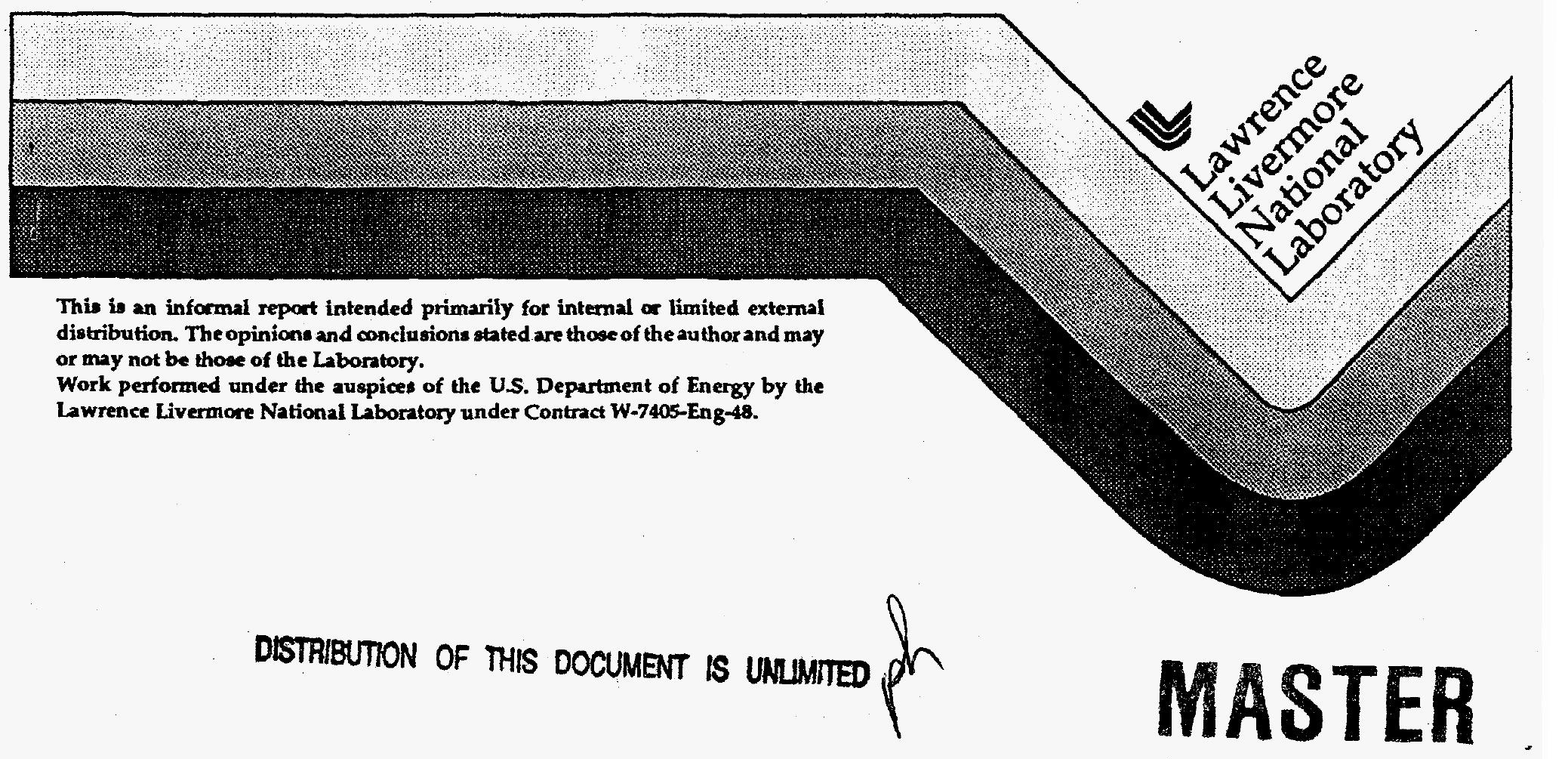




\section{DISCLAMMER}

This document was prepared as an acoount of work sponsored by an agency of the United States Covernment. Nelther the United States Covernment nor the University of Callfornia nor any of their employees, makes any warranty, exprew or implied, or asoumes any legal linbility or responsibility for the cocuracy, completeneas, or unefulnem of any information, apparatus, product, or process disclosed or represents that th use would not infringe privately owned rights. Reference herein to any specific commercial product, procese, or service by trade nume, trademark, manufacturer, or otherwlee, does not necesearily constitute or imply its endorsement, recommendation, or fovoring by the United States Covernment or the Univereity of Californin. The views and opinions of authors expressed herein do not necessarily state or reflect those of the United States Covernment or the University of California, and shall not be used for advertising or product endorsement purposes.

This report has been reproduced directly from the best available copy.

Available to DOE and DOE contractors from the Office of Scientific and Technical Information P.O. Box 62, Oak Ridge, TN 37831

Prices available from (615) 576-8401, FTS 626-8401

Available to the public from the National Technical Information Service

U.S. Department of Commerce 5285 Port Royal Rd. Springfield, VA 22161 


\section{DISCLAIMIER}

Portions of this document may be illegible in electronic image products. Images are produced from the best avallable original document. 


\title{
PRELIMINARY REPORT
}

\section{THE BLACK THUNDER, WYOMING CTBT R\&D EXPERIMENT QUICKLOOK REPORT: LLNL INPUT FROM REGIONAL STATIONS}

\author{
P.E. Harben and L.A. Glenn
}

\begin{abstract}
This report presents a preliminary summary of the data recorded at three regional seismic stations from surface blasting at the Black Thunder Coal Mine in northeast Wyoming. The regional stations are part of a larger effort that includes many more seismic stations in the immediate vicinity of the mine. The overall purpose of this effort is to characterize the source function and propagation characteristics of large typical surface mine blasts. A detailed study of source and propagation features of conventional surface blasts is a prerequisite to attempts at discriminating this type of blasting activity from other sources of seismic events.
\end{abstract}

\section{Introduction}

The Black Thunder Seismic experiment is a joint LANL/LLNL/AFTAC verification effort to determine seismic source and path effects that result from very large, but routine ripple-fired surface mining blasts. Studies of the data collected will be for the purpose of understanding how the near-field and regional seismic waveforms from these surface mining blasts are similar to, and different from, point shot explosions and explosions at greater depth. Detailed seismic waveform data were collected within the mine property to help determine explosion-source characteristics. Three temporary regional stations were established to collect waveform data on source and path effects, and a fourth permanent regional seismic station at Pinedale was included.

This short report gives a quick look at the temporary regional station data collected during the course of the deployment. Most of the information in this report has been submitted for inclusion in a larger LANL quicklook report that will cover all aspects of this experiment.

\section{Station Locations and Features}

Three temporary regional stations were installed on this experiment. The station sites were chosen to lie along the line between the AFTAC Pinedale seismic station and the Black Thunder Mine. The stations were installed and all on-line by $6 / 15 / 95$ and were all recovered from the field on $9 / 19 / 95$.

All stations employed 3-components, using Teledyne Geotech model GS-13 seismometers. 
These instruments can resolve low-level background seismic noise in the 0.1 to $50 \mathrm{~Hz}$ frequency band and have a nominal free period of $1 \mathrm{sec}$. The data were recorded with 16-bit Reftek data acquisition units in the event detect mode. Event parameters are:

gain - 32x

sample rate -250 samples/sec.

trigger channels - vertical only

short term average (STA) - $1 \mathrm{sec}$.

long term average (LTA) - $10 \mathrm{sec}$.

triggering ratio -3.5

The station locations from the Black Thunder Mine, as determined by single receiver GPS, is shown in the table below:

\begin{tabular}{|c|c|c|c|c|c|}
\hline Station ID & Latitude & Longitude & $\begin{array}{l}\text { Elevation } \\
\text { (m) }\end{array}$ & $\begin{array}{l}\text { Distance } \\
\text { from mine } \\
(\mathrm{km})\end{array}$ & $\begin{array}{l}\text { Bearing to } \\
\text { mine }\end{array}$ \\
\hline BHS & $\mathrm{N}_{44^{\circ}}^{\circ}$ 07.290' & $W 104^{\circ} 02.227^{\prime}$ & 1959 & 111.7 & $242^{\circ}$ \\
\hline MON & $\mathrm{N}^{\prime} 3^{\circ} 12.014^{\prime}$ & $\mathrm{W} 107^{\circ} 42.153^{\prime}$ & 1738 & 203.5 & $075^{\circ}$ \\
\hline TIS & $N 43^{\circ} 26.581^{\prime}$ & W106 $28.818^{\prime}$ & 1529 & 100.8 & $076^{\circ}$ \\
\hline
\end{tabular}

Coordinate accuracy is a nominal 25 meters on latitude and longitude and about $50 \mathrm{~m}$ on altitude.

The exact location of the mine was arbitrarily chosen as the location of a small coal shot conducted on 12/14/94 at 15:52 local time at the coordinates N43 39.27 latitude and W105 16.05 longitude.

\section{Black Hills Site (BHS)}

The Black Hills station (BHS) is a Designated Seismic Station (DSS) that was constructed for temporary occupancy by the Former Soviet Union seismic verification scientists in accordance with the Threshold Test Ban Treaty protocol. This seismic site is under the guardianship of the On Site Inspection Agency (OSIA), who generously agreed to our temporary use of the site. The seismometers were placed on a vault pier (see Figure 1) at about 5 meters depth that provided excellent coupling to the underlying bedrock.

The BHS site is remote from heavily traveled roads, situated on top of a hill on National Forest property. 


\section{Tisdale Mountain Site (TIS)}

The Tisdale station (TIS) is located on the edge of a large anticline that forms the Tisdale mountain complex. Shallow soils and exposed bedrock are prevalent in the site vicinity. The site is on BLM land.

The deployment site is remote, well away from frequently traveled roads, as shown in Figure 2. The site conditions were excellent for seismic coupling to the underlying bedrock. The seismometers were buried at a nominal depth of about 1 meter on competent sandstone bedrock as shown in Figure 3.

\section{Moneta Site (MON)}

The Moneta station (MON) site is located in the Wind River Basin. The site is on the Lost Cabin Member of the Wind River Formation. This lower to middle Eocene facies consists of fine grained gray to greenish gray siltstones, claystones, and sandstones. The depth to Precambrian bedrock at this site is 6,000-7,500 meters. The site is on BLM land.

The deployment site is relatively remote, as shown in Figure 4 with the nearest heavily traveled two lane road at least 5 miles away. The site conditions were not optimal for coupling of the seismometers to underlying bedrock. The seismometers were buried at a depth of $3 \mathrm{ft}$. in fairly well consolidated sand.

\section{Recorded Data}

Of the large number of events that were recorded at each station, we have only attempted to look for 12 events as of this writing. These events were determined by LANL to include the most important large cast shots and a collection of smaller representative coal shots. Results from the 3 regional stations show that 4 of the five large cast shots were event-detected and recorded at all three stations. The cast shot that was not recorded occurred prior to installation of the regional stations.

The five smaller coal shots were not event detected at every station. These shots were much smaller than the cast shots and simply did not always trigger an event detect at regional distance despite the fact that the triggering ratio was set to be reasonably sensitive to small events. Station BHS triggered for four of the six coal shots, TIS for two, and MON did not trigger for any. A summary of the recording results for the selected 12 events is shown in the following table: 


\begin{tabular}{|c|c|c|c|c|c|c|}
\hline Event & Type & $\begin{array}{l}\text { \# of } \\
\text { Holes }\end{array}$ & TIS & MON & BHS & Notes \\
\hline $\begin{array}{l}\text { Number } 1 \\
06131620\end{array}$ & $\begin{array}{l}\text { Cast } \\
3204 \mathrm{~K} \text { lbs }\end{array}$ & 403 & $\cdots$ & -- & $\cdots$ & $\begin{array}{l}\text { prior to station } \\
\text { installation }\end{array}$ \\
\hline $\begin{array}{l}\text { Number } 2 \\
06161909\end{array}$ & $\begin{array}{l}\text { Cast } \\
4738 \mathrm{~K} \text { lbs }\end{array}$ & 704 & $z, e$ & $z, n$ & z,n,e & $\begin{array}{l}\text { TIS - } 160 \mathrm{sec} \\
\text { MON }-60 \mathrm{sec} \\
\text { BHS - } 160 \mathrm{sec}\end{array}$ \\
\hline $\begin{array}{l}\text { Number } 3 \\
06232337\end{array}$ & $\begin{array}{l}\text { Cast } \\
2266 \mathrm{~K} \text { lbs }\end{array}$ & 274 & $z, e$ & $z, n$ & $\mathrm{z}, \mathrm{n}, \mathrm{e}$ & $\begin{array}{l}\text { TIS }-160 \mathrm{sec} \\
\text { MON }-60 \mathrm{sec} \\
\text { BHS }-110 \mathrm{sec}\end{array}$ \\
\hline $\begin{array}{l}\text { Number } 4 \\
07181947\end{array}$ & $\begin{array}{l}\text { Cast } \\
3658 \mathrm{~K} \text { lbs }\end{array}$ & 454 & $z, e$ & $z, n$ & $z, n, e$ & $\begin{array}{l}\text { TIS }-160 \mathrm{sec} \\
\text { MON }-160 \mathrm{sec} \\
\text { BHS }-160 \mathrm{sec}\end{array}$ \\
\hline $\begin{array}{l}\text { Number } 5 \\
07251919\end{array}$ & $\begin{array}{l}\text { Cast } \\
3559 \mathrm{~K} \text { lbs }\end{array}$ & 567 & $\mathrm{z}, \mathrm{e}$ & $\mathrm{z}, \mathrm{n}$ & $\mathrm{z}, \mathrm{n}, \mathrm{e}$ & $\begin{array}{l}\text { TIS - } 60 \mathrm{sec} \\
\text { MON - } 60 \mathrm{sec} \\
\text { BHS - } 160 \mathrm{sec}\end{array}$ \\
\hline $\begin{array}{l}\text { Number } 6 \\
06172200\end{array}$ & $\begin{array}{l}\text { Coal } \\
12 \mathrm{~K} \text { lbs }\end{array}$ & 10 & $--\cdot$ & -- & --- & event is small \\
\hline $\begin{array}{l}\text { Number } 7 \\
06201935\end{array}$ & $\begin{array}{l}\text { Coal } \\
102 \mathrm{~K} \text { lbs }\end{array}$ & 54 & $z, e$ & $\cdots$ & $z, n, e$ & $\begin{array}{l}\text { TIS }-110 \mathrm{sec} \\
\text { BHS }-60 \mathrm{sec}\end{array}$ \\
\hline $\begin{array}{l}\text { Number } 8 \\
07021830\end{array}$ & $\begin{array}{l}\text { Coal } \\
29 \mathrm{~K} \mathrm{lbs}\end{array}$ & 20 & $\cdots$ & $\cdots$ & $z, n, e$ & BHS - $60 \mathrm{sec}$ \\
\hline $\begin{array}{l}\text { Number } 9 \\
07022138\end{array}$ & $\begin{array}{l}\text { Coal } \\
64 \mathrm{~K} \text { lbs }\end{array}$ & 34 & $\cdots$ & $\cdots$ & $\mathrm{z}, \mathrm{n}, \mathrm{e}$ & BHS $-60 \mathrm{sec}$ \\
\hline $\begin{array}{l}\text { Number } 10 \\
07082141\end{array}$ & $\begin{array}{l}\text { Coal } \\
101 \mathrm{~K} \text { lbs }\end{array}$ & 54 & $z, e$ & $\cdots$ & $z$ & $\begin{array}{l}\text { TIS }-160 \mathrm{sec} \\
\text { BHS }-60 \mathrm{sec}\end{array}$ \\
\hline $\begin{array}{l}\text { Number } 11 \\
07122227\end{array}$ & $\begin{array}{l}\text { Coal } \\
344 \mathrm{~K} \text { lbs }\end{array}$ & 186 & $\cdots$ & $\cdots$ & --- & $\begin{array}{l}\text { reason for trigger } \\
\text { failure is not clear }\end{array}$ \\
\hline $\begin{array}{l}\text { Number } 12 \\
08241951\end{array}$ & $\begin{array}{l}\text { Sim. } \\
\text { 50K lbs }\end{array}$ & & & & & $\begin{array}{l}\text { data not recovered } \\
\text { yet }\end{array}$ \\
\hline
\end{tabular}


The information listed in columns headed by a station identifier refer to the seismometer components that were successfully recorded (z-vertical, $n$-north/south, e-east/west). The full record length of the seismic recordings for each station is given in the Notes column. Each record includes about ten seconds of pre-event data. The final event in the table, number 12, was an unusual "zero-delay" event that will be extremely useful in subsequent analysis by serving as an empirical Green's function.

\section{Data Characteristics}

The large cast shots present the most complete regional data set at present. An example of the vertical component waveforms from the three stations is shown in Figure 5 for event 07181947. Although the BHS and TIS sites are about $100 \mathrm{~km}$ from the source, the waveform amplitude at the BHS site is about twice what it is at the TIS site. This is probably a path or site effect since it is observed for different source orientations and firing sequences.

Figure 6 shows the power spectral density of event 07181947 for the vertical component of the three stations. The power spectral density was calculated using 10 seconds of the initial $P$-wave record at each station. Of particular interest is the significantly larger amplitude of the BHS station in the $8-15 \mathrm{~Hz}$ band compared to the TIS amplitude. This difference dominates the appearance of the spectrograms which follow.

The spectrograms for the first 50 seconds of waveform are shown for events 06161909 , 06232337, 07181947, and 07251919 at all three stations in Figures 7,8,9 and 10 respectively. Of particular interest in these spectrograms is the frequency band containing the dominant energy of the waveform. In all cases the TIS and MON sites have a nominal frequency of dominant energy at about 5-7 Hz. The BHS site, however, has a dominant frequency in the range of 10-15 $\mathrm{Hz}$. Since the BHS and TIS site are at comparable distances from the explosion sources and the sources are in different pits and orientations, the spectral differences are probably the result of a path and/or site effect.

\section{Summary}

Many hundreds of events have been recorded at each station. We have only catalogued 11 specific events that originated at the Black Thunder Mine. These events, however, include 4 major explosions exceeding 2 million lbs of explosive agent. Furthermore, detailed explosion layout plans - source parameters - are known for these events.

Preliminary analysis indicates that the path to and/or site at BHS results in greater amplitudes and higher frequency content in the recorded waveforms than the path to and/or site at TIS and MON. This appears to be independent of source characteristics.

Numerous other events have been recorded that originated from other mines in the basin. Our intent is to archive the ground truth and seismic data from all these events and to use the resulting data base to help answer the following questions: 
1) Under what circumstances will ripple-fired events not yield modulated spectra?

2) How is spectral modulation dependent on source-receiver range and azimuth?

3) On what source parameters does seismic magnitude mainly depend?

4) What fraction of large mining events can be discriminated from earthquakes, rockbursts and "point source" underground explosions?

\section{Acknowledgments}

We thank Pat Lewis, Don Rock, and Jerry Sweeney for expert support in the field. We are also indebted to the Bureau of Land Management for land use permission for the MON and TIS sites. The On Site Inspection Agency were very accommodating in providing the BHS site for our temporary use. Thanks also to the LANL crew who provided coordination support and event source data. 


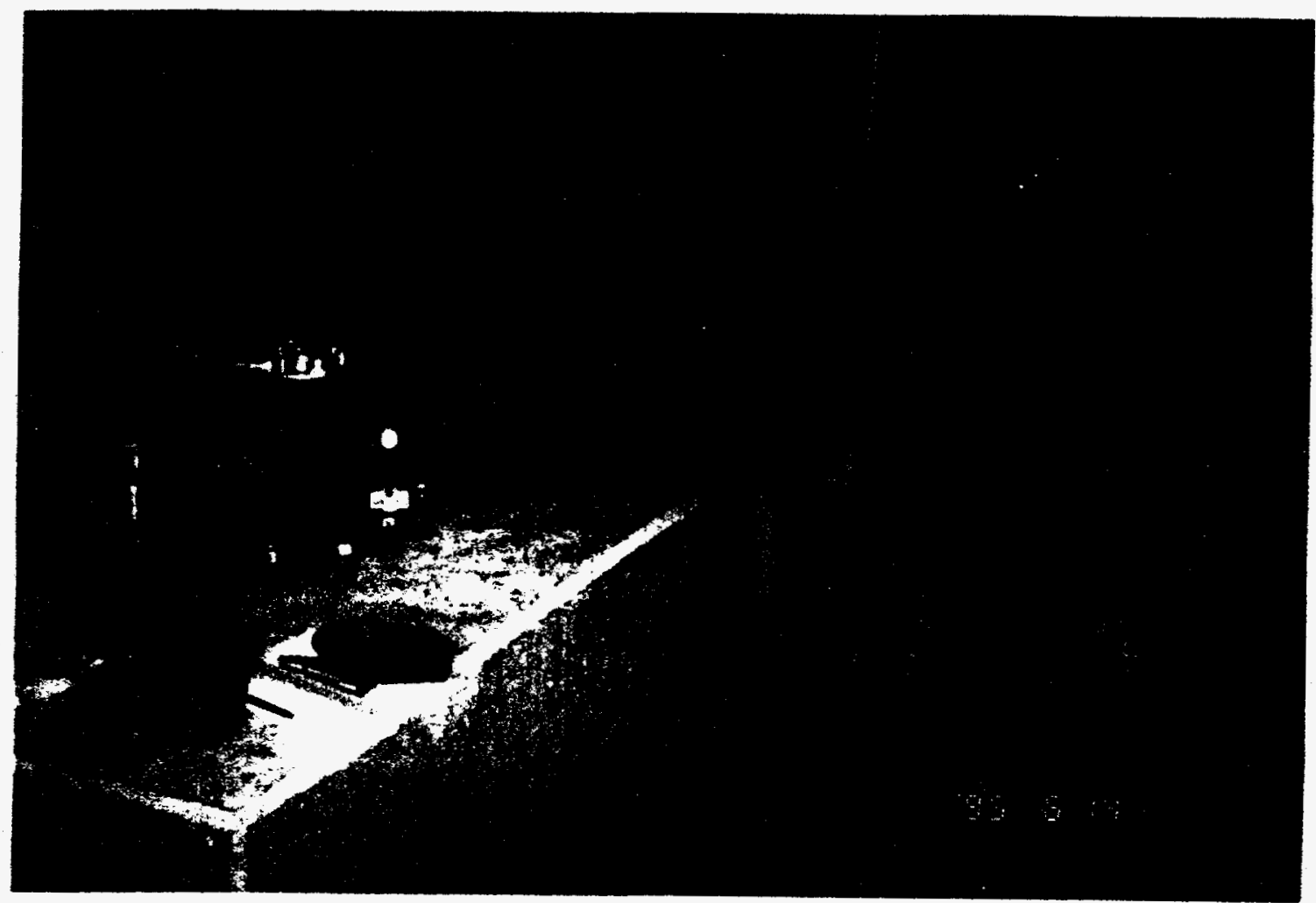

Figure 1: Photo showing the GS-13 seismometers on the vault pier at the BHS station

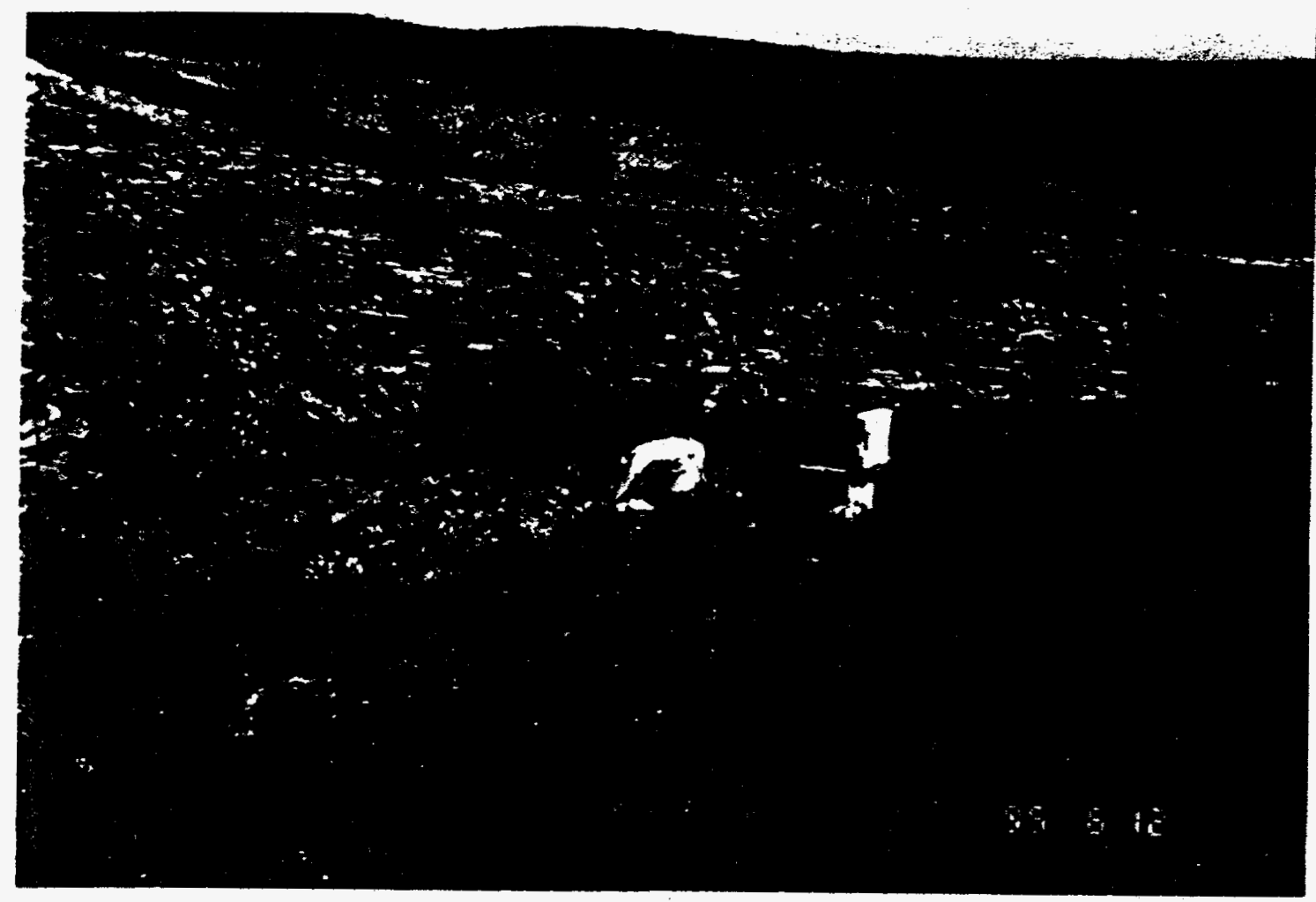

Figure 2: Photo showing the location and surroundings of the TIS station. 


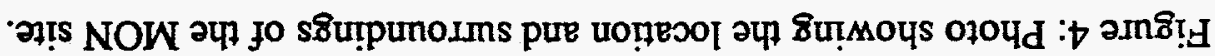

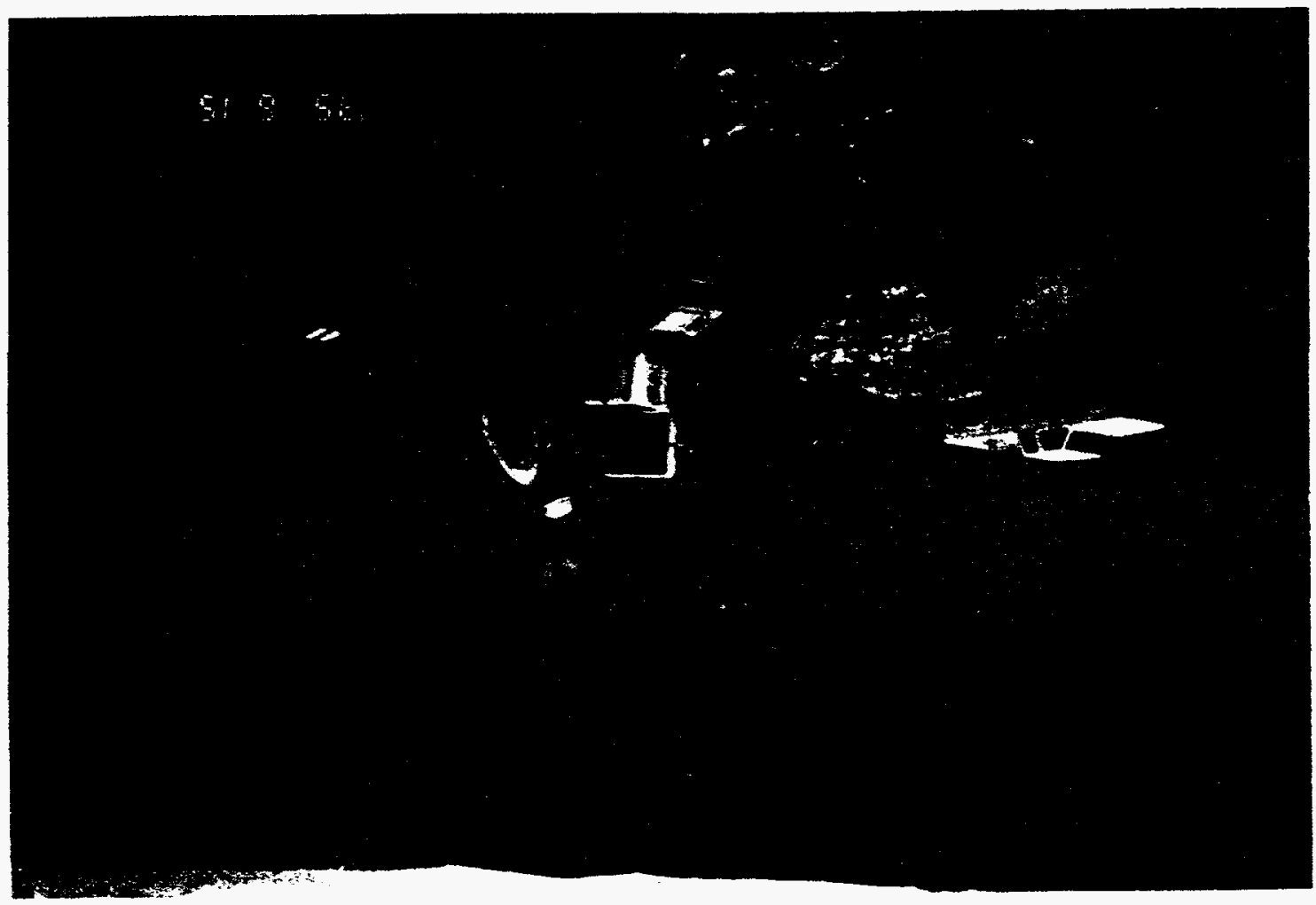

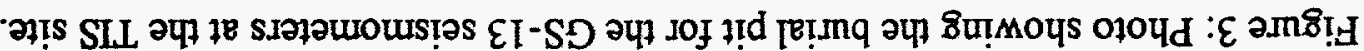

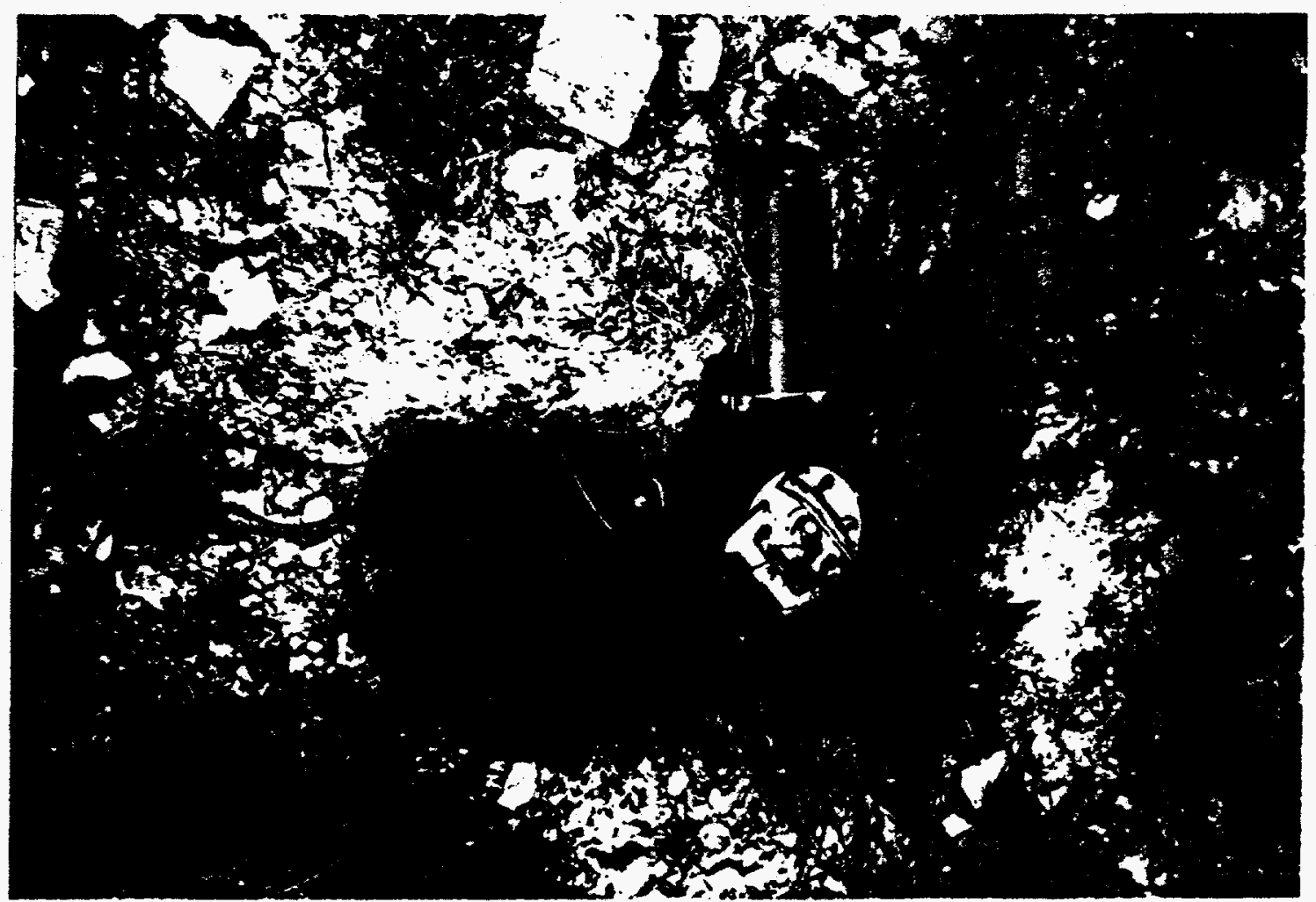




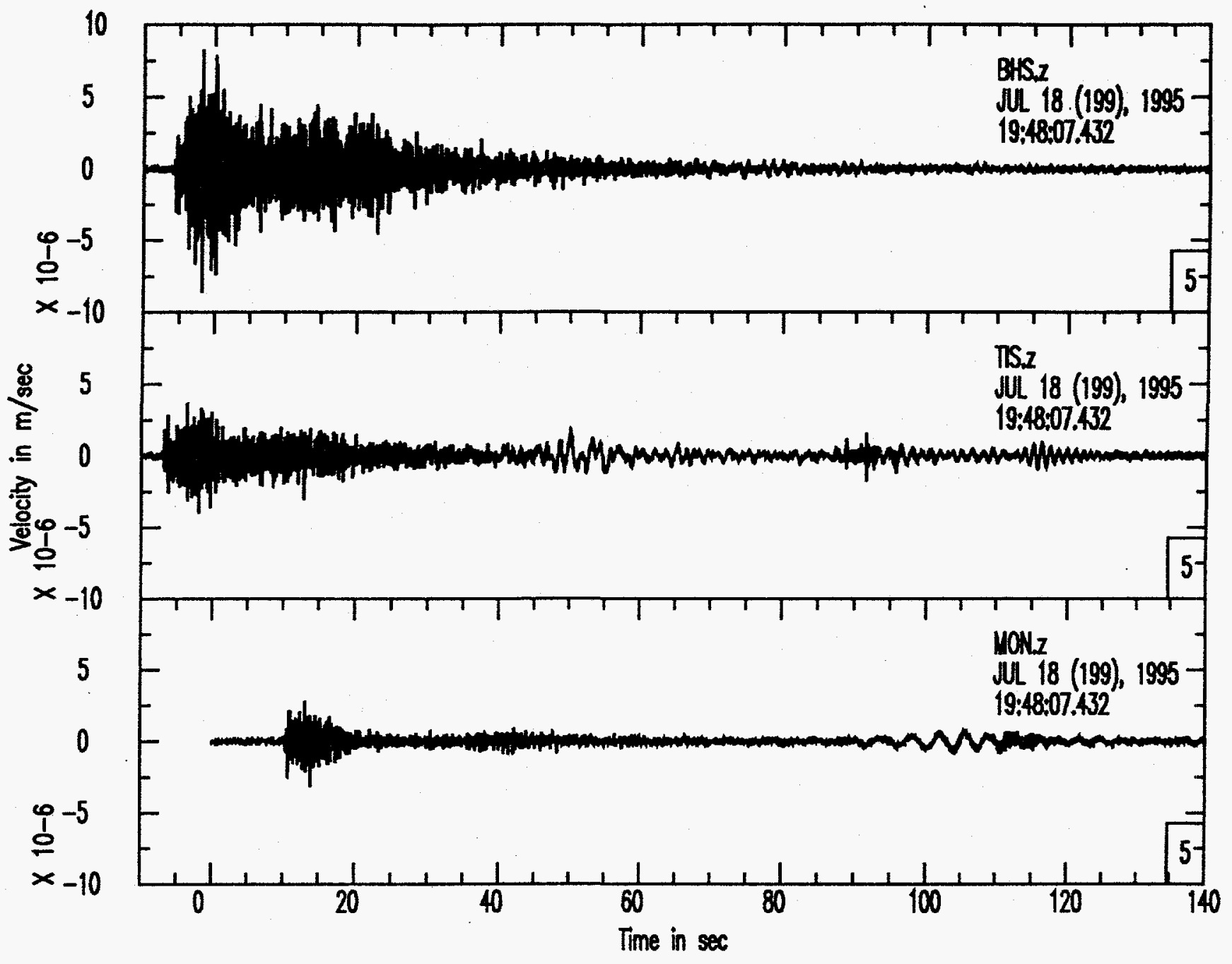

Figure 5: Waveforms for event 07181947 showing relative amplitude of the three station recordings. 


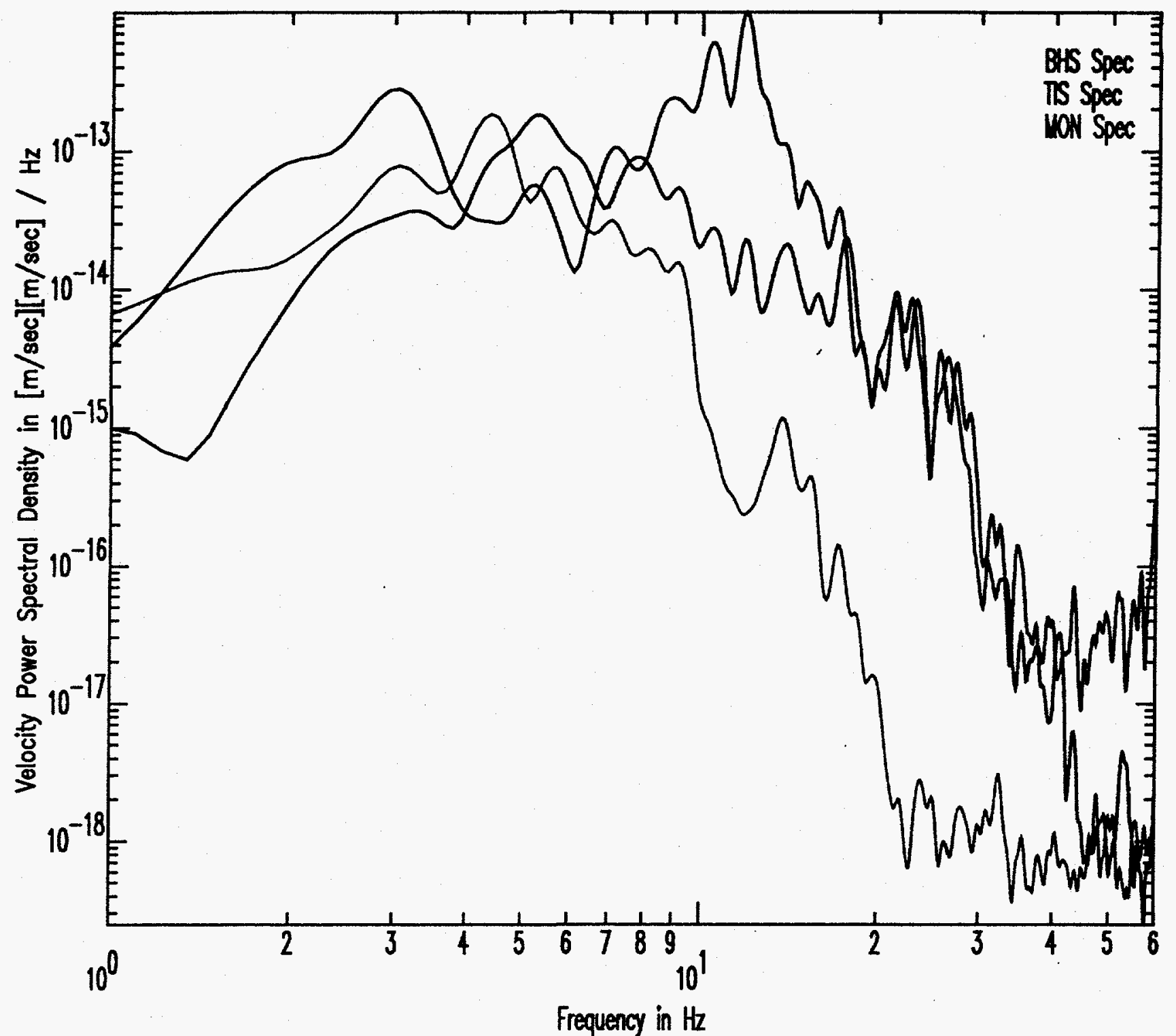

Figure 6: Power Density Spectra for the first 10 seconds of record at the three regional stations. Only the P-wave phase is represented in these spectra. 


\section{Event 06161909}
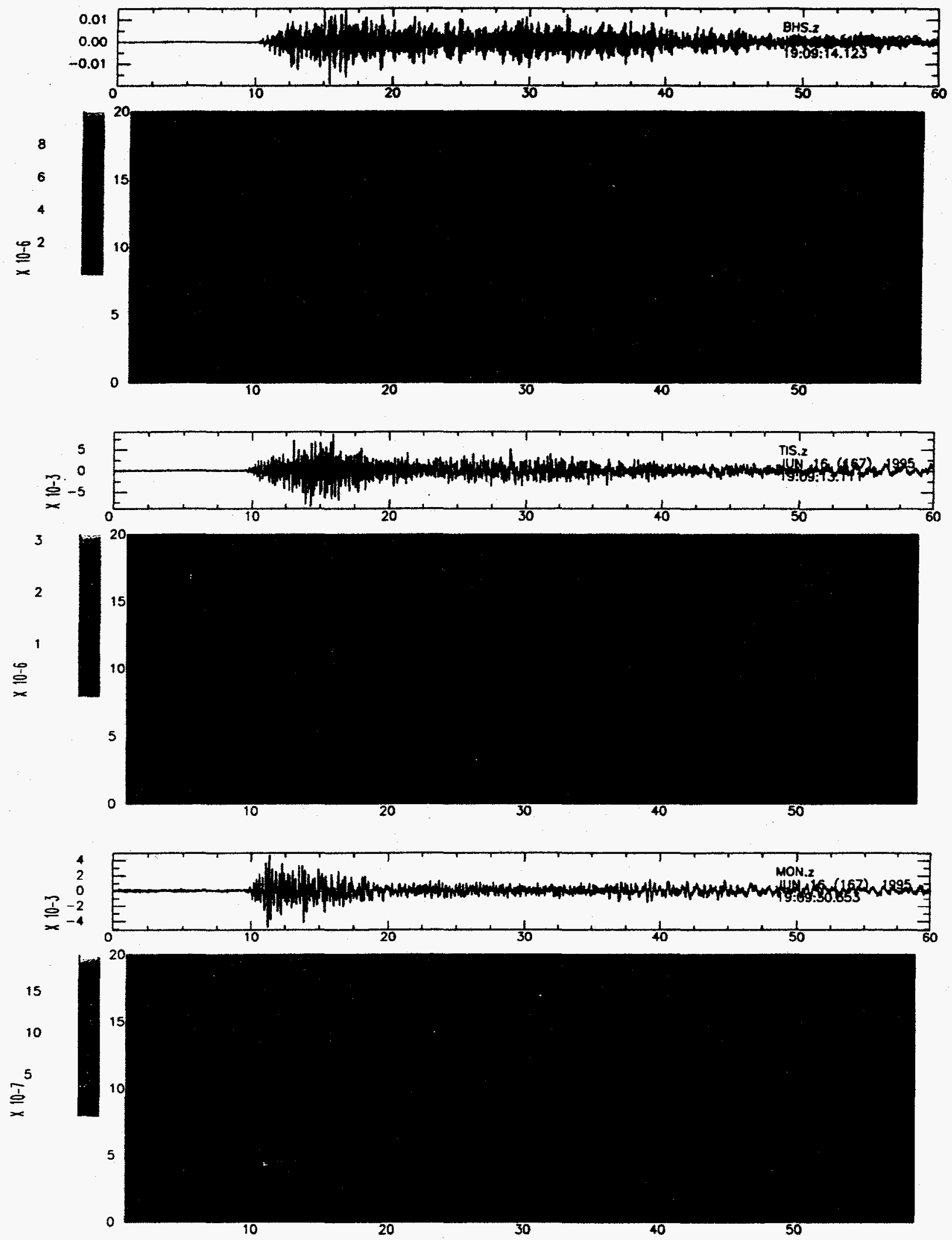

Figure 7: Spectrograms for BHS (top), TIS (middle), and MON (bottom) 


\section{Event 06232337}
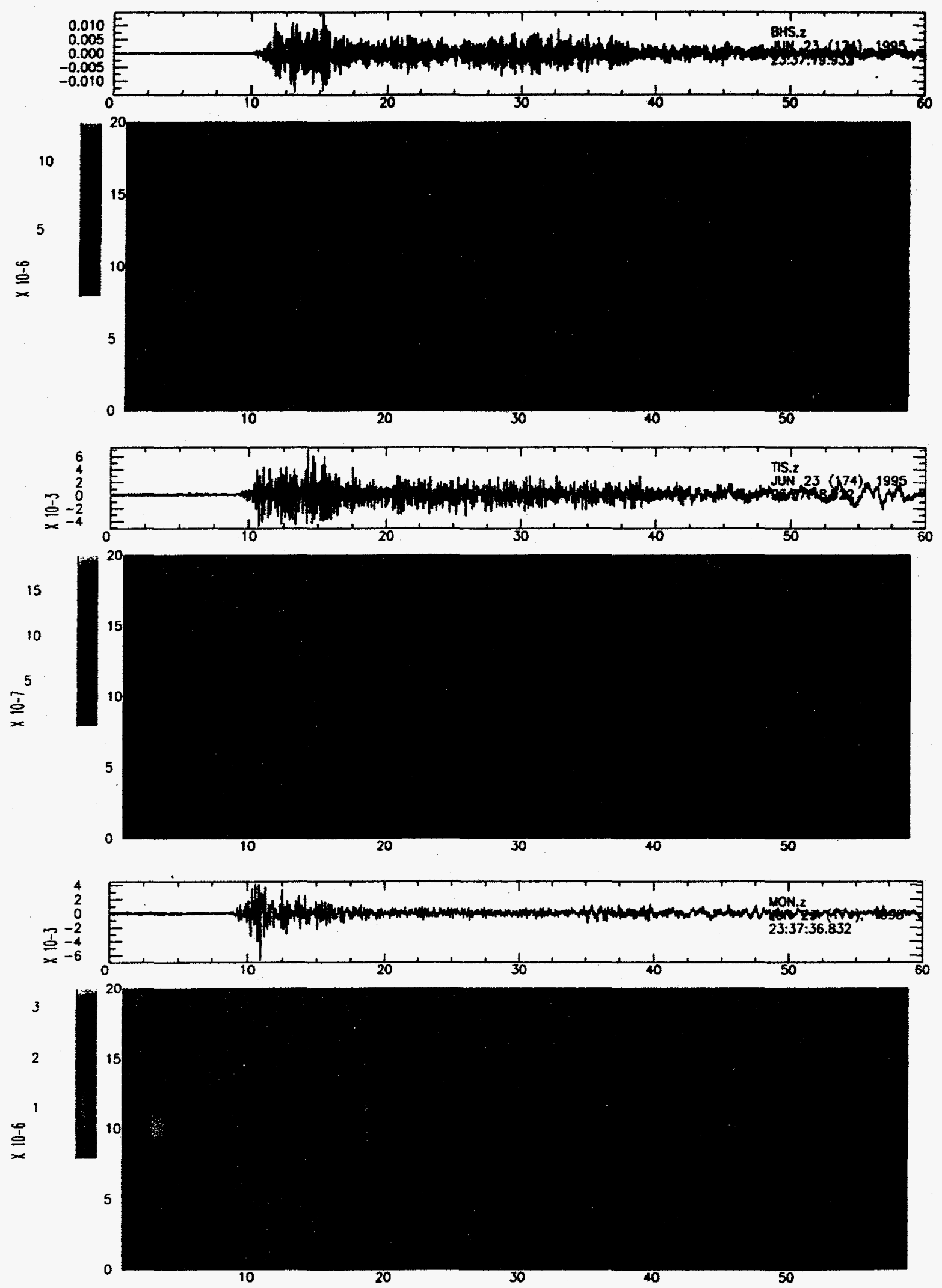

Figure 8: Spectrograms for BHS (top), TIS (middle), and MON (bottom) 


\section{Event 07181947}
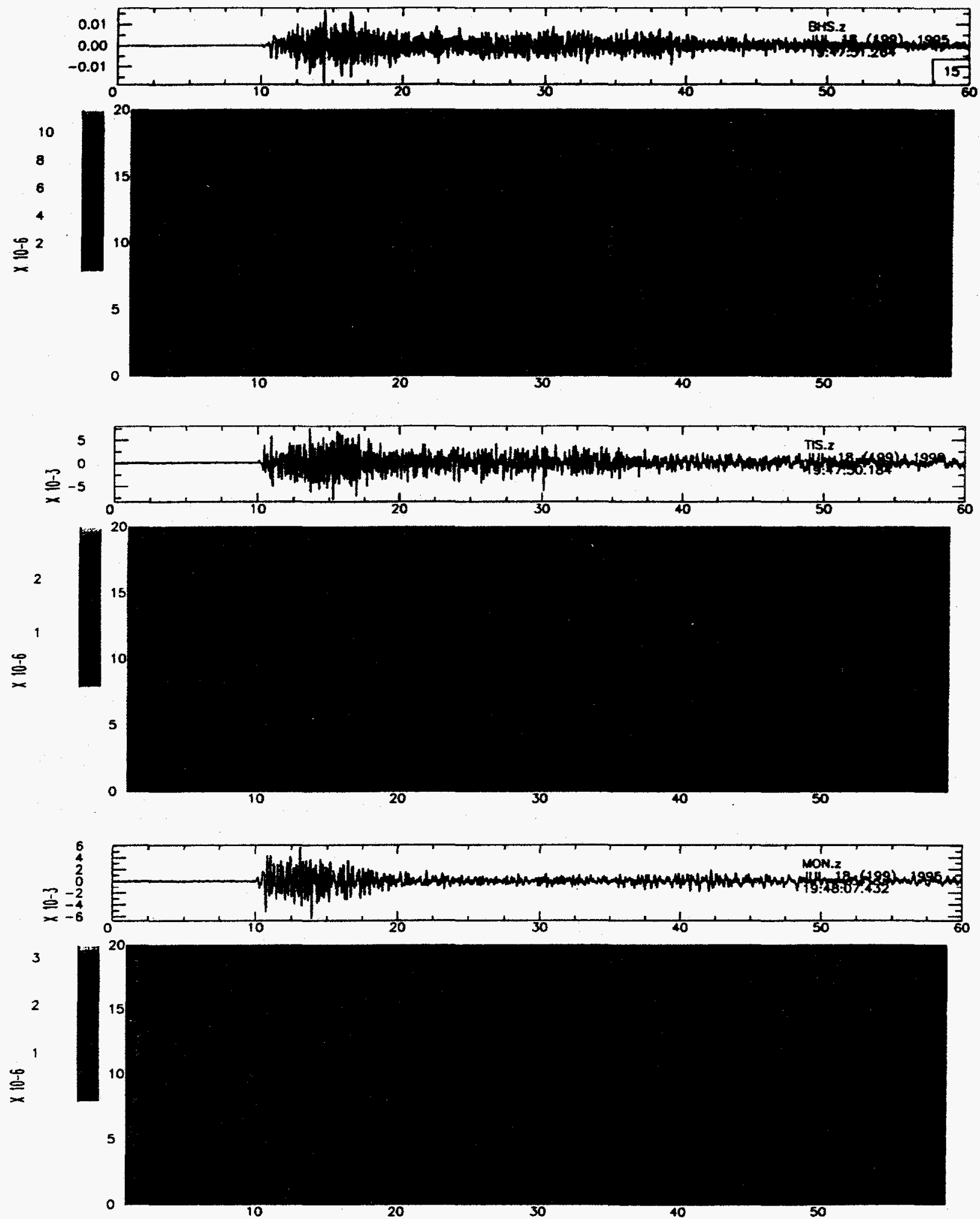

Figure 9: Spectrograms for BHS (top), TIS (middle), and MON (bottom) 


\section{Event 07251919}
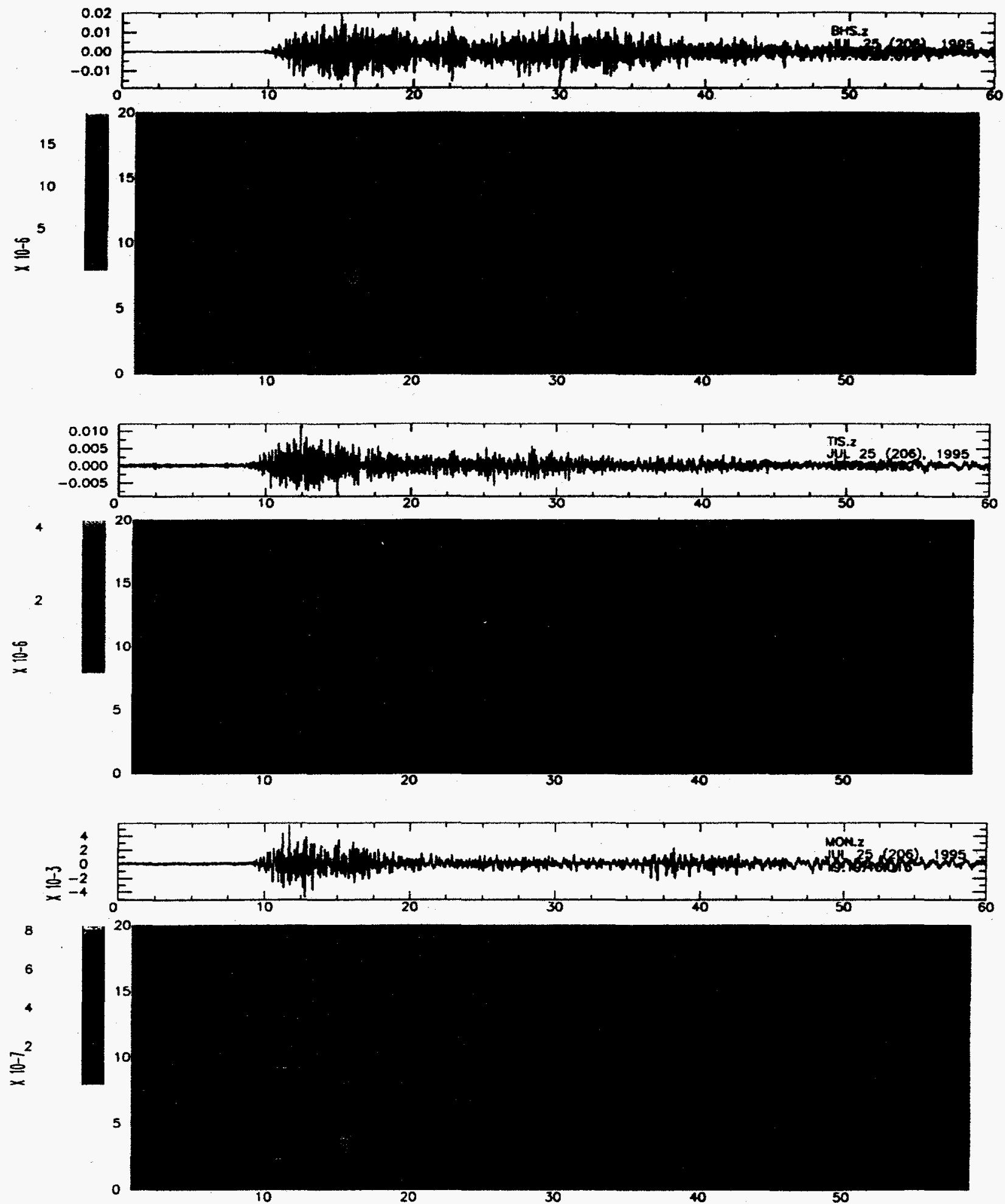

Figure 10: Spectrograms for BHS (top), TIS (middle), and MON (bottom) 